\title{
Research on Construction of Entrepreneurship Incubator Base under the “Government-University-Enterprise” Co-cultivation Mechanism
}

\author{
Bing Bai ${ }^{1}$,A-jun Guo ${ }^{1, *}$,Kai Wang ${ }^{2}$ \\ ${ }^{1}$ Beihua University ,Jilin, China \\ ${ }^{2}$ Beihua University, College of physical education, Longteng innovation and entrepreneurship education base \\ *Corresponding author
}

Keywords: Innovation and Entrepreneurship, Incubator Base, "Government-University-Enterprise” Co-Cultivation.

\begin{abstract}
Government-university-enterprise" co-cultivation mechanism is an effective way for colleges and universities to cultivate innovative talents and the inevitable trend of higher education development in China. On the premise of understanding basic principles and functions of entrepreneurship incubator base construction in colleges and universities, this paper utilizes "government-university-enterprise" linkage mechanism, fully develops professional features and advantages of colleges and universities, and delves into entrepreneurship incubator base construction, in order to form positive interaction of all-win situation, make full use of stakeholders of multiple parties in talent cultivation, knowledge formation and achievement transformation, and achieve the education and teaching objective of co-cultivation.
\end{abstract}

In the context of “mass entrepreneurship and innovation”, university students' entrepreneurship incubator base provides a good service platform for entrepreneurship and practice of university students, thus becoming one of the most important embodiment forms of entrepreneurship education achievements ${ }^{[1]}$ and an important standard to evaluate scientific and technological level of colleges and universities ${ }^{[2]}$. University students' entrepreneurship incubator base is launched comprehensively. Thus, how to develop and steadily promote the reform of innovation and entrepreneurship education is a new problem facing colleges and universities.

\section{Basic Principles of University Students' Entrepreneurship Incubator Base Construction}

Based on Guiding Opinions on Accelerating the Building of the Platform for Supporting Mass Entrepreneurship and Innovation of the State Council and Implementation Options on Promoting Innovation and Entrepreneurship Education Reform in Colleges and Universities of General Office of the State Council, on-campus incubator base construction should adhere to following principles to create good environment for innovation and entrepreneurship.

\subsection{Insisting on cultivating students foremost and enhancing quality}

Regard the construction of entrepreneurship incubator base as the breakthrough and important step of facilitating comprehensive reform of innovation and entrepreneurship education in colleges and universities. Based on talent cultivation objective of colleges and universities and objective of innovation and entrepreneurship education, promote the deep integration between innovation and entrepreneurship education and professional education, between innovation and entrepreneurship education and entrepreneurship practical training, between entrepreneurship practical ability cultivation and establishment of small and micro enterprises on the practice platform of 
entrepreneurship incubator base, so as to enhance overall quality of talents comprehensively.

\subsection{Insisting on encouraging entrepreneurship and gathering resources}

Respect objective rules of innovation and entrepreneurship, give full play to the decisive function of market allocation of resources, give priority to the funds of colleges and universities, introduce the cooperative mode of government capital and social industry capital, jointly establish a new entrepreneurship and innovation service platform; focus on demand of industry development, emphasize the development and introduction of intermediate and advanced technologies, middleand high-level entrepreneurship projects, lead university students and the masses to conduct entrepreneurship, develop new type of business, strengthen new economy; fully make use of administrative power of the government to promote the formation of inner power of innovating system, forming policies, gathering talents, offering financial support, coordinating all parties and conducting innovation and entrepreneurship in colleges and universities, so as to collect such resources as funds, policies and talents from all sectors of society ${ }^{[3]}$, deal with contradiction, offer service, create and optimize the environment for innovation and entrepreneurship.

\subsection{Insisting on innovative service and continuous development}

Implement innovation and entrepreneurship service improving project, develop entrepreneurship incubator base into an influential innovation and entrepreneurship comprehensive service platform. Through marketization mechanism, specialized service, capitalized operation and low-cost and high-efficient convenient service, improve efficiency and quality of entrepreneurship service. Adopt the market-oriented operation mode suitable for the development incubator base in colleges and universities, efficiently gather entrepreneurship service resources, innovation operation modes and profit model, achieve profit objective, enhance success rate and survival rate of entrepreneurship, realize continuous and healthy development of the base.

\section{Management Modes of Existing University Students' Entrepreneurship Incubator Bases}

\subsection{Colleges and universities independent management}

Construction of university students' entrepreneurship incubator base plays an important role in education management activity of colleges and universities. Colleges and universities should finish investment of funds, management of devices and determination of operation objective independently, and then combine its management mode with those of government and enterprises to realize construction and management of university students' entrepreneurship part ${ }^{[4]}$.

\subsection{Government management}

The government power-dominated management mode of university students' entrepreneurship incubator base mainly relies on policies and funds of government ${ }^{[5]}$ and meets the demand of university students with intention of entrepreneurship. Currently, the mode of government management has weakness in terms of professionalism and advancement. It should follow the development rules of market economy and combine with real situation of entrepreneurship incubator base construction in colleges and universities, so as to improve management efficiency.

\subsection{Government-university management mode}

In 2001, our country established the first batch of university students' entrepreneurship incubator bases. The management mode was government-dominated university management [6, 7]. The operation mechanism was government-university co-operation, followed development rules of market economy, combined with operation ability of the government, realized smooth operation of university students' entrepreneurship incubator base. The government could provide colleges and universities with fund and policy support.

\subsection{Enterprise-university management mode}

This mode is based on university-enterprise cooperation. A smooth information communication 
channel between enterprise and university should be established according to the development demand of university students' entrepreneurship incubator base, thus enabling the two parties to finish management work jointly through exchanging and sharing information ${ }^{[8]}$. Universities can provide enterprises with necessary research achievements, while enterprises can furnish university students with enough entrepreneurship practice space. Usually, management activity is usually finished by universities. Such management mode of university-enterprise cooperation has received wide attention in current market economy environment and strong support from our country and government, thus contributing a lot to the smooth operation of university students' entrepreneurship incubator base.

\section{Strategies of Entrepreneurship Incubator Base Construction under “Government-University-Enterprise” Co-cultivation Mechanism}

\subsection{Establishing linkage working mechanism, forming working situation of cooperative engagement}

Normative system and procedure and good environment are the basis of realizing "government-university-enterprise" cooperation and basic guarantee for enterprises participating in talent education in colleges and universities. "Government-university-enterprise” linkage will allow each party to perform its own functions and give full play to its advantages. Promotion and guidance of government and guarantee of policies and laws will fully arouse universities' and enterprises' enthusiasm for cooperation, avoid various risks during project incubation process efficiently, and facilitate the implementation of "government-university-enterprise" cooperation.

\subsection{Optimizing institutional system, guaranteeing smooth operation of "government-univ ersity-enterprise” cooperation}

As for specific operation process, government should play the role of supervision and evaluation, endow enterprises with due preferential and awarding policies justly, and promote smooth implementation of incubator base construction. Colleges and universities can establish various incentive systems to encourage project incubation. Meanwhile, colleges and universities can make use of the cooperation with enterprises to adjust professional talent cultivation plans, perfect professional course setting, accelerate education reform and actually implement "government-university-enterprise" co-cultivation work.

\subsection{Collecting multiple resources, strengthening entrepreneurship tutor group}

As for construction of entrepreneurship tutor group, on one hand, on-campus teacher resources should be fully explored, especially those having entrepreneurship experience or succeeding in entrepreneurship in order to enrich the teacher group for university students' innovation and entrepreneurship education; on the other hand, entrepreneurs willing to devote to university students' innovation and entrepreneurship education and people with successful entrepreneurship experience can be employed as tutors. Moreover, various forums can be organized irregularly to share practical entrepreneurship experience and improve success rate of university students' entrepreneurship.

\subsection{Building policies information platform, offering precise service}

To support entrepreneurship of the youth, both the central government and local governments have issued plenty of preferential policies successively. For university students with plan of entrepreneurship, learning and taking advantage of these policies is the first step. In fact, the perfect degree and implementation of supporting policies will influence the enthusiasm and success rate of entrepreneurship directly. Through effective policy promotion and cultivation agency, "government-university-enterprise" cooperation will equip ambitious young people with enough projects, technologies, information and funds. 


\section{Conclusion}

The construction of innovation and entrepreneurship incubator base in colleges and universities is a heavy task and has a long way to go. The construction and management modes of the base still need further improvement. The sense of urgency and responsibility of developing innovation and entrepreneurship education in colleges and universities should be reinforced practically. Efforts should be paid to recognize oneself, give full play to advantages, integrate resources, gather strength to promote innovation and entrepreneurship incubator base development in colleges and universities, and form a new pattern of "government-university-enterprise” co-cultivation and joint development.

\section{References}

[1], Jiang Kaidong, Zhu Jianqiong. Research on University Oriented Cooperative Mechanism of college students [J]. Chinese higher education research, 2015, (01): 54-58.

[2] Xue Chenglong, Lu Caichen, Li Duanmiao. "12th Five-Year" during the review and Reflection on innovation and entrepreneurship education in Colleges and Universities -- Based on the analysis of higher education "third party assessment report" [J]. China higher education research, 2016, (02): 20-28+73.

[3]], Zeng Yifan. Research on service function design of incubator for college students [J]. Journal of Hebei Youth Administritive Cadre Institute, 2016,28 (05): 15-20.

[4], Liu Kun, Wang Gang. Research on the main management models of college students incubation base [J]. intelligence, 2016, (10): 184-185.

[5] Zhuang Yimin. Under the background of government decentralization in the entrepreneurial role in [J]. Journal of Chongqing Jiaotong University (SOCIAL SCIENCE EDITION), 2015,15 (06): 106-109.

[6], Huang Zhaoxin, Wang Zhiqiang, Liu Chanjuan. The dimension of the development of entrepreneurship education in local universities [J]. educational research, 2015,36 (02): 59-66+157.

[7] Liu Jinrong, the main management mode of university students. The Chunxiao single incubation base analysis of [J]. China adult education, 2009 (02): 25-26

[8], Shi Guizhou, Yu Xia. Research on the development of University Transformation under the collaborative innovation of industry and technology [J]. vocational and technical education, 2016,37 (22): 14-19. 